\title{
The Effects of Situational Factors in the Implementation of Work-Based Learning Model on Vocational Education in Indonesia
}

\section{Dwi Rahdiyanta}

Department of Mechanical Engineering Education Faculty of Engineering, Yogyakarta State University, Indonesia, dwi_rahdiyanta@uny.ac.id

\section{Didik Nurhadiyanto}

Department of Mechanical Engineering Education Faculty of Engineering, Yogyakarta State University, Indonesia

\section{Sudji Munadi}

Department of Mechanical Engineering Education Faculty of Engineering, Yogyakarta State University, Indonesia

This study aimed at investigating the effects of situational factors consisting of school culture, corporate culture, and the performance of management institution to the readiness of student work in implementing Work-Based Learning (WBL) model on vocational education in Indonesia. The present study was primarily carried out with a quantitative approach using a survey methodology. The research was conducted in the Mechanical Engineering Study Program, Faculty of Engineering, Yogyakarta State University and in the Machining Industry in Yogyakarta, Bandung and Semarang. The study was conducted within 6 months, from March to September 2018. The population of the study was all students (85 students) who took the complex machining process course. The research sample consisted of 32 people selected by purposive sampling technique. In this case, the study sample was students who have carried out industrial practice. Data were collected using questionnaires and test. Questionnaires were used to retrieve student responses data on situational aspects and their readiness to work in machining practices on soft-competence aspects. The test was used to retrieve data on the readiness of students to work on aspects of hard-competence. Content validity was established by expert judgment. Data were analyzed using descriptive analysis, regression and path analysis, using a significance level of 0.05 .

Keywords: effects of situational factors, work-based learning, vocational education, learning model, teaching 


\section{INTRODUCTION}

Vocational education as a part of the national education system in Indonesia plays a very strategic role in generating competent and professional labors. The competent and professional labors are demanded to possess the knowledge and basic skills to adapt to the demand and the existing dynamics of developments in the career world. Therefore, to face the strict competition in this globalization requires labors who perform not only working skills in a specific field (hard competencies) but also abilities to handle and to benefit the changes (soft competencies). Hence, it becomes a challenge for vocational education to integrate the two components and to prepare the students for possessing working skills and to develop themselves in the future.

The learning should focus on the educating process. Consequently, the learning should not merely transfer the knowledge. It means that learning do not provide chances to do interactions and transactions among the students. For this reason, the learning should provide practices of critical thinking and social interaction for the students. The learning process also requires taking into account the soft-skills, i.e. collaboration, mutual respect, sense of belonging, sense of responsibility, honesty, and sacrifice.

Vocational education is an educational program which heavily concerns with students' preparations before entering the career world. Furthermore, Axmann (2015), state that vocational education is defined as education that provides supplies for students to work for supporting their lives. Vocational education has some characteristics: 1) directed to prepare learners for entering workplaces, 2) based on "demand-driven", 3) emphasized on the knowledge mastery, skills, attitudes and values needed in the career world, 4) based on "hands-on" or work performance assessments, 5) supported by close relationships with the career world as the key to achieve a successful vocational education, 6) emphasized on responsive and anticipatory advancements of technology, 7) emphasized more on learning by doing and hands-on experiences, 8) completed by up-to-date facilities for practices, and 9) supported by greater investments and operational costs than general education. The emphasis of vocational education is to equip the students with a set of skills and abilities that can be applied in a particular work field or to develop themselves in accordance with the work fields.

Vocational education is part of the educational system that prepares a person to be able to work in one work group or one occupational field than other fields of work (Evans \& Heer, 1978). Clark \& Winch (2008) states that "vocational education is confined to prepare young people and adults for workforce, a process that is often rather than technical and practical nature". Vocational education is an educational program that is directly connected with the preparation of someone to enter the workforce, or for additional preparation needed in a career (Calhoun and Finch, 1982). Furthermore, Finch and Crunkilton (1984) state that vocational education is defined as education that provides provision to students to be able to work to support their lives. Meaning that vocational education is education to enter employment and is intended for anyone who wants it, who needs it, and who can benefit from it. 
From the different points of views mentioned above, the concern for vocational education in Indonesia as well as other developing countries is that existing facilities especially facilities for practical activities on campus are inadequate and have not received good support from the industry. With limited practice facilities on campus, students cannot develop their skills optimally. Therefore, if learning is only done on campus the quality of students who graduate will not fit into the requirements demanded by the world of work or industry. To overcome this problem, WBL learning is very important to be applied to vocational education in Indonesia. In order to have the implementation of WBL run well, it is necessary to have good cooperation between the campus and the industry. To support this cooperation to achieve its best, MOU and regulation from the government that strengthens the importance of cooperation between the campus and the industry in order to produce superior and noble human resources are needed.

One of the efforts to produce graduates who are ready to work in the machining field and to meet the career demands is implementing a Work-Based Learning (WBL) model on vocational education of Diploma III Mechanical Engineering study program. WBL model can be a means of the integration of hard competencies and soft competencies. In vocational education, WBL model is appropriately applied to practical courses. This is very reasonable because practical courses are the core and the nature of vocational education. Therefore, the development of machining practices in vocational education should be continuously done so that the quality of its graduates meets the demands of the machining field. Thus, experiential learning theories, contextual teachings, and Work-Based Learning become very relevant to the implementation of vocational education.

\section{CONTEXT AND REVIEW OF LITERATURE}

In nowadays contemporary education praxis, constructivism is widely used as the basis of the learning paradigm. It produces teaching methods that emphasize the main activities of students, and emphasize them to have the ability to develop their own knowledge (Fosnot, 1996; Lorsbach \& Tobin, 1992). Constructivism requires active participation in solving problems with authentic and contextual learning activities that are relevant to students.

One form of contextual learning is Work-Based Learning (WBL). WBL is a contextual teaching and learning approach that integrates workplace activities with activities in the classroom (Smith, 2001; Berns \& Erickson, 2001). The WBL approach is derived from the premise that learning settings in the real workplace context, not only make academic learning easier for learners but also increase engagement in schooling industries / workplaces (Wonacott, 2002). Activities in school help strengthen and expand the learning achieved at the workplace. With WBL students can develop attitudes, knowledge, and skills from experience in two places, namely in schools and workplaces / industries while learning is also possible with real-life work activities (Lynch \& Harnis, 1998). 
Work-Based Learning (WBL) as a learning approach plays a role in improving professional development and learning. WBL is used as terminology in various countries for programs at schools / colleges to gain experience from the world of work. WBL is also used to give teenagers the ability to be ready for the transition from school to the world of work to learn the reality of the world of work / work so that they become ready to make the right choices in work (Paris \& Mason, 1995).

A Work-Based Learning (WBL) is an approach of CTL (Contextual Teaching and Learning) that provides workplace activities integrated into learning contents. Implementing WBL in teaching and learning processes helps to strengthen and to develop competencies to be achieved at work fields (Karen Vaughan, 2017). Also, the implementation of WBL connects the learning process with real work activities (Rooney, 2015). To implement WBL properly, vocational education of Mechanical Engineering should collaborate with associate companies of the machining field. In addition, learning outcomes are assessed by indicators: (1) hard-skill mastery consisting of theories and machining practices, and (2) soft-skill mastery consisting of professional attitude, work preparedness, and independence.

Factors affecting the implementation of WBL in vocational education can be grouped into two: situational factors and learning factors. Situational factors include school culture, corporate culture, and institutional performance. In contrast, the learning process factors are affected by lecturers, students, curricula, and learning facilities. The learning process will be better if it involves qualified educators and students (smart, highly motivated and well-behaved). Also it should be supported by learning resources or optimal learning facilities.

As stated Balkar (2015), school culture is a set of values that underlie behaviors, traditions, habits, and symbols practiced by school leaders, teachers, administrators, students, and communities around the school. School culture is characteristics, personalities, and images of the institution in a wider community. Schools must set a mission to create a challenging, fun, fair, creative, integrative and dedicated culture to achieve its vision to produce highly qualified graduates. Highly qualified graduates have indicators of being cautious, honest, creative, model, hardworking, tolerant and competent in leading and answering challenges of human resource development needs. The organizational culture at schools also has a correlation with the teachers' attitudes in working. The study by Cheng (2000) proves that stronger school cultures had bettermotivated teachers. In an environment with strong organizational ideology, shared participation, charismatic leadership and intimacy, teachers experienced higher job satisfaction and increased productivity.

A qualified vocational education should collaborate with the business and industrial worlds. Therefore, school culture is closely related to corporate culture. The corporate culture acts as shared values and describes the pattern or the behaviors of a company. Culture plays a role in anticipating and adapting to various changes and existing developments (Keep, 2015). The corporate culture is shaped by the institutional history process, through a combination of policy management, traditions, and philosophical values that guide it. Regarding the integration of different aspects, which enhances 
corporate culture, the culture of each institution/ company differs from one to another. This means that corporate culture plays an important role in managing the changes that arise due to the demands of innovations.

In addition, corporate culture is an important part in the determination of institutional strategies. Shefi (2005) identifies six main keys of cultural traits that support the implementation of institutional strategies: (1) intensive communication among the development teams (2) skill awards, (3) delegation of authority enabling the institutional community to take timely actions, (4) involvement of experienced and knowledgeable management in operational activities, (5) passionate and trustworthy communities of institutions to have power to act and (6) organizational conditioning to be innovative and flexible to handle the changes.

Institutional performance is expected to affect both learning processes and learning outcomes. This is very reasonable because the managers must be directly involved in modeling, planning, implementing, monitoring, supervising, and evaluating the implementation of Work-Based Learning. The institutional performance is indicated by effective communication, good coordination, appropriate conflict resolution, appropriate problem solving, effective implementation of decisions, and effective and efficient management of WBL programs. Arie de Geus (2002) conducted a study of the "living corporate" concept and found out that the still-standing institutions are capable to create "living corporate" in their organizations, even in a highly competitive environment. The living corporate will be succeeded if the leader is able to enhance commitments to value people, learnings, and innovations in the company/ institution. Therefore, both managers and communities within the institution must commit to (1) be adaptable, (2) take initiatives to change in accordance with market demands, (3) undertake business/ investment measures that can be accounted for, and (4) increase trusts to stakeholders.

The success of the institutional performance can be observed through the process and product performance. The process performance is a reflection of the efficiency performed by the management in using resources when being in charge to handle the process of innovative developments. The efficiency of the innovation management then becomes a basis for the next measure of the product performance. The success of the process performance can be indicated by the effectiveness of products or graduates. The efficiency in process performance means minimization of cost and time, while the effectiveness means the achievements of innovation targets that have been set. Product performance is the effectiveness resulted from the management team of vocational education. When the product is proper or even exceeding the expectation, a management team is considered to have respectable product performance.

\section{Relevant Research}

In order to find out the impact of the WBL on student learning outcomes, several research results will be presented.

Hardwick-Franco (2018), in his paper on flexible education in Australia, stated that Work-Based Learning has an impact on students having a broader and more 
comprehensive view. It facilitates them improve their ability to make decisions, improve personal development, and improve their professional quality.

According to the results of research on the implementation of work-based education in vocational education in the United States, WBL provides a transformative impact that combines responsibility, ethics, cooperation, hard work, discipline, and mutual respect reflected in work (Wall, Hindley, Hunt, Peach, Preston , Hartley and Fairbank, 2017; Wall and Meakin, 2018; Wall and Hindley, 2018).

The results of other studies state that work-based learning in the field of drama art has a positive impact on the ability to explore, experiment, and play drama seriously (Pässilä et al., 2017; Wall, T., Bellamy, L., Evans, V. and Hopkins, S. (2017); Österlind, E., 2018).

Based on the results of the research conducted by Trisiswanto, B. (2015), regarding the implementation of Work-based Learning models on students of Diploma III in the Automotive Engineering Study Program in Indonesia, it was found that WBL learning had a positive impact on improving automotive mechanic knowledge, professional attitude, work mental readiness, and student independence.

From the various research results on the implementation of Work-based learning (WBL), it can be concluded that its implementation can improve student work readiness both in the aspects of soft -competence and hard-competence aspects. Therefore, a research on the implementation of WBL is needed in order to improve students' work readiness, especially in the field of machining.

In conclusion, it is very important to know the effects of situational factors consisting of school culture, corporate culture, and institutional performance in the implementation of WBL model on the learning outcomes machining practices in vocational education.

\section{Research Hypothesis}

The hypotheses tested in this study are: 1) There is a significant effect of School Culture, Corporate Culture, and Institutional Performance on the WBL Learning Process, and 2). There is a significant impact of School Culture, Corporate Culture, Institutional Performance and WBL Learning Process on Students' readiness for work.

\section{METHOD}

The present study was primarily carried out with a quantitative approach using a survey methodology, which aimed to investigate the effects of situational factors on the learning outcomes of machining practices using Work-Based Learning (WBL) model.

The population of this research was the Diploma III students of Mechanical Engineering, Faculty of Engineering, Yogyakarta State University, who were taking a course of Complex Machining. The population of the study was 85 students. The sample of the research was 32 students determined by a purposive sampling technique. In this case, the study sample was students who have carried out industrial practice. The study 
was conducted in corporate partner (in the machining industry) and in engineering workshop of Faculty of Engineering, Yogyakarta State University.

The data were collected using questionnaires and tests. The questionnaires were used to collect the data on school culture, corporate culture, WBL learning processes, and learning outcomes related to soft-skills (professional attitude, job readiness, and independence). Meanwhile, the test was used to collect data on learning outcomes related to the knowledge mastery in machining processes. The validities of the instruments included content and construct validity. The content validity of the instrument was examined through an expert's judgment with the Delphi technique. The Delphi technique was implemented in two rounds by involving academic experts and industrial practitioners in the machining field through Focus Group Discussions (FGD).

The Delphi technique is a systematic method for gathering experts' opinions (Skulmoski, Hartman, and Krahn (2007). For the preparation and validation of the contents of instruments, this study involved 6 experts, consisting of 3 experts from the academic field of machining field, and 3 experts from machining industry practice. The steps taken to validate the research instruments with Delphi techniques were: 1) establishing Delphi, 2) formulating problems, 3) recruiting appropriate experts and ensuring that they understand the objectives of the study, 4 ) preparing and distributing the first stage questionnaires, 5) revising the results of the first stage questionnaires and preparing the second stage questionnaires, and 6) determining consensus.

To test the construct validity of this research instrument, confirmatory factor analysis with the PCA (Principal Component Analysis) method and the varimax system rotation were used. Instrument items that do not meet the criteria in this study were aborted and excluded from the data collection instruments. The results of factor analysis on the test construct validity can be seen in table 1 .

Table 1

Factor Analysis Results

\begin{tabular}{|c|c|c|c|c|c|c|}
\hline \multirow[b]{2}{*}{ Variables } & \multirow[b]{2}{*}{$\begin{array}{l}\text { Number } \\
\text { of items }\end{array}$} & \multicolumn{4}{|c|}{ Fall Grain Number } & \multirow{2}{*}{$\begin{array}{l}\text { Number } \\
\text { of valid } \\
\text { items }\end{array}$} \\
\hline & & $\begin{array}{l}\text { MSA } \\
<0,5 \\
\end{array}$ & $\begin{array}{l}\text { Communality } \\
<0,25\end{array}$ & $\begin{array}{l}\text { Loading } \\
\text { Factor }<0,32\end{array}$ & $\begin{array}{l}\text { Invalid Items } \\
\text { Number }\end{array}$ & \\
\hline (X1) & 15 & 3,13 & - & - & 2 & 13 \\
\hline (X2) & 24 & 6 & 10,18 & - & 3 & 21 \\
\hline (X3) & 17 & 3,4 & 10 & 15 & 4 & 13 \\
\hline (X4) & 28 & 5, & - & - & 2 & 26 \\
\hline$(\mathrm{Y})$ & 11 & - & - & - & - & 11 \\
\hline Total & 95 & 7 & 3 & 1 & 11 & 84 \\
\hline
\end{tabular}

Note:

$\mathrm{X} 1=$ School Culture; $\mathrm{X} 2=$ Corporate Culture; $\mathrm{X} 3=$ Institutional Performance $\mathrm{X} 4=$ WBL Learning Process; $Y=$ Readiness of Student Work

Criteria for the magnitude of the number of instrument reliability coefficients are determined based on various views. According to Ebel (1972: 275), the magnitude of a good reliability coefficient is 0.80 , while according to Nunnally (1978: 83) is 0.75 
according to Feldt \& Brennan (1989: 77) is 0.70 and according to Thorndike and Hagen (1984) is 0.5 .

The calculation results of instrument reliability by looking at the Alpha coefficient from Cronbach with the help of the SPSS for Windows version 17 program are shown in Table 2.

Table 2

Instrument Reliability Calculation Results

\begin{tabular}{llll}
\hline No. & Variables & Alpha Coefficient & Conclusion \\
\hline 1. & $\mathrm{X} 1$ & 0,766 & Reliable \\
\hline 2. & $\mathrm{X} 2$ & 0,781 & Reliable \\
\hline 3. & $\mathrm{X} 3$ & 0,835 & Reliable \\
\hline 4. & $\mathrm{X} 4$ & 0,883 & Reliable \\
\hline 5. & $\mathrm{Y}$ & 0,792 & Reliable \\
\hline
\end{tabular}

Note:

$\mathrm{X} 1=$ School Culture; $\mathrm{X} 2=$ Corporate Culture; $\mathrm{X} 3=$ Institutional Performance X4= WBL Learning Process; Y= Readiness of Student Work

The data analysis techniques consisted of descriptive analysis and inferential analysis (hypothesis testing) which included correlation analysis, regression and path analysis. Prior to the data analysis, the testing of assumptions that included tests of normality, linearity, homoscedasticity, and multicollinearity was completed. The relationship among variables in this study is shown in Figure 1.

$$
\rho_{y \times 2}
$$

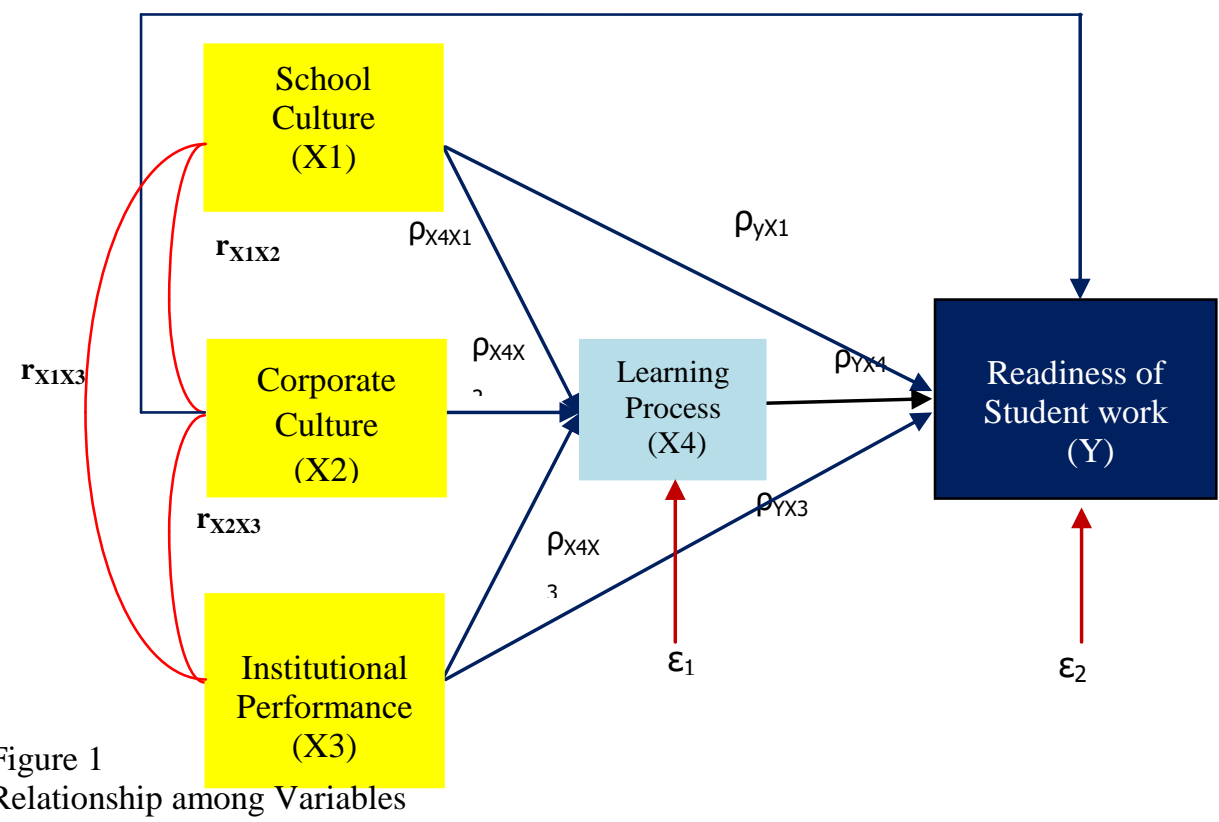

International Journal of Instruction, July $2019 \bullet$ Vol.12, No.3 
The following writing and referencing rules are to be taken into consideration.

The articles need to be not published elsewhere previously. If the article has been presented at any seminar or conference, the name of the conference, the institution where it has been presented and the date of the presentation needs to be mentioned. The Journal is written in English. Thus, the articles need to be written in this language.

\section{FINDINGS}

The data descriptions include the measurement of frequency distributions, standards of central tendencies (mean, mode, median), standard deviation, and descriptive interpretations of variables: school culture (X1), corporate culture (X2), institutional performance (X3), WBL learning processes (X4), and the readiness of Student work (Y). The data analysis is presented in Table 3.

Table 3

Results of Data Analysis

\begin{tabular}{lllllllll}
\hline Var. & SD. & Mi & M & Me & Mo & M : Mi & $\begin{array}{l}\text { Score } \\
\text { Achieve- } \\
\text { ments (\%) }\end{array}$ & Category \\
\hline $\mathrm{X} 1$ & 7.40 & 66 & 80.24 & 80.00 & 80 & Greater & 75.9 & High \\
\hline $\mathrm{X} 2$ & 12.15 & 63 & 113.45 & 112.00 & 112 & Greater & 76.1 & High \\
\hline $\mathrm{X} 3$ & 12.33 & 39 & 128.41 & 128.00 & 122 & Greater & 72.3 & High \\
\hline $\mathrm{X} 4$ & 16.86 & 54 & 157.40 & 157.50 & 159 & Greater & 83.6 & High \\
\hline $\mathrm{Y}$ & 14.80 & 51 & 256.45 & 257.00 & 249 & Greater & 81.0 & High \\
\hline
\end{tabular}

Taking into account the descriptive analysis, the empirical mean values (M) are greater than criteria mean value (Mi). Also, it is found in table 1 that the achievement values for all research variables were above $70 \%$. This means that all variables in this study are generally included in the high category.

\section{Correlations of Research Variables}

The correlation among research variables can be investigated by testing the hypothesis: There is a significant correlation among research variables, i.e. school culture (X1), corporate culture (X2), institutional performance (X3), WBL learning processes (X4), and readiness of student work $(\mathrm{Y})$. To test this hypothesis, the researchers applied a no rank correlation analysis of research variables using product moment from Pearson. In response to the correlation analysis among research variables in Table 2, it is concluded that the hypothesis stating there is a positive and significant correlation among variables is accepted and tested at the significance level of 0.05 . The correlation analysis among research variables is presented in Table 4. 
Table 4

$\underline{\text { Summary of Correlation Analysis of Nil Levels Among Variable Research }}$

\begin{tabular}{lllllll}
\hline & & $\mathrm{X} 1$ & $\mathrm{X} 2$ & $\mathrm{X} 3$ & $\mathrm{X} 4$ & $\mathrm{Y}$ \\
\hline \multirow{2}{*}{$\mathrm{X} 1$} & Pearson Correlation & 1 & 0.292 & 0.383 & 0.561 & 0.374 \\
& Sig. & & 0.000 & 0.000 & 0.000 & 0.000 \\
\hline \multirow{2}{*}{$\mathrm{X} 2$} & Pearson Correlation & 0.292 & 1 & 0.355 & 0.231 & 0.372 \\
& Sig. & 0.000 & & 0.000 & 0.000 & 0.000 \\
\hline \multirow{2}{*}{$\mathrm{X} 3$} & Pearson Correlation & 0.383 & 0.355 & 1 & 0.448 & 0.545 \\
& Sig. & 0.000 & 0.000 & & 0.000 & 0.000 \\
\multirow{2}{*}{$\mathrm{X} 4$} & Pearson Correlation & 0.561 & 0.231 & 0.448 & 1 & 0.651 \\
& Sig. & 0.000 & 0.000 & 0.000 & & 0.000 \\
\hline \multirow{2}{*}{$\mathrm{Y}$} & Pearson Correlation & 0.374 & 0.372 & 0.545 & 0.651 & 1 \\
& Sig. & 0.000 & 0.000 & 0.000 & 0.000 & \\
\hline
\end{tabular}

Effects of School Culture (X1), Corporate Culture (X2), Institutional Performance (X3) on WBL Learning Processes (X4) (Quality Determination of WBL Learning Processes).

The effects of school culture, industrial culture, and institutional performance on WBL learning processes can be examined by testing the hypothesis: There are significant effects of school culture (X1), corporate industry culture (X2), and institutional performance (X3) on WBL learning processes (X4). This hypothesis was tested through a multiple regression analysis by placing $\mathrm{X} 4$ as the dependent variable and $\mathrm{X} 1, \mathrm{X} 2$ and $\mathrm{X} 3$ as the independent variables. The multiple regression analysis is presented in Table 5.

Table 5

Multiple Regression Analysis of Variable X4 on Variables X1, X2 and X3

\begin{tabular}{|c|c|c|c|c|c|c|c|c|}
\hline $\begin{array}{l}\text { Dep. } \\
\text { Var. }\end{array}$ & $\begin{array}{l}\text { Indep. } \\
\text { Var. }\end{array}$ & B & Beta & $\mathrm{r}_{\mathrm{par}}$ & $\begin{array}{l}\text { Partial } \\
\text { Det. } \\
\left(\mathrm{r}^{2}{ }_{\text {par }}\right)\end{array}$ & $\mathrm{t}_{\text {total }}$ & Sig. $t$ & Summary \\
\hline \multirow{3}{*}{$\mathrm{X}_{4}$} & $\mathrm{X}_{1}$ & 0.501 & 0.430 & 0.473 & 0.224 & 8.237 & 0.000 & \multirow{3}{*}{$\begin{array}{l}R=0.714 \\
R^{2}=0.510 \\
F=101.724 \\
P<005 \\
C=17.251\end{array}$} \\
\hline & $\mathrm{X}_{2}$ & 0.140 & 0.107 & 0.144 & 0.021 & 2.499 & 0.012 & \\
\hline & $\mathrm{X}_{3}$ & 0.528 & 0.360 & 0,414 & 0.171 & 7.827 & 0.000 & \\
\hline
\end{tabular}

The multiple regression analysis in table 5 shows that F-total is 101.724 at $p$-value which is lower than 0.05 . As a result, the correlation coefficient $(\mathrm{R})=0.714$ is significant at the significance level of 0.05 . Concerning the analysis, the hypothesis stating there is are significant effects of school culture (X1), corporate culture (X2), and institutional performance (X3) on WBL learning processes (X4) is accepted. The coefficient of determination $\left(\mathrm{R}^{2}\right)=0.510$ shows that the contribution of these three variables is $51 \%$.

Independently, school culture (X1) has a significant effect on the learning processes $(\beta=$ 0.430: $\mathrm{p}>0.05)$; corporate culture (X2) has a significant effect on the learning processes 
$(\beta=0.107: \mathrm{p}>0.05)$; and institutional performance (X3) has a significant effect on the learning processes $(\mathrm{X} 4) ;(\mathrm{B}=0.360$ : $\mathrm{p}>0.05)$.

Considering the coefficient of partial determination, school culture has the greatest contribution to the learning processes $(22.4 \%)$, followed by institutional performance $(17.1 \%)$, and corporate culture $(2.1 \%)$. Thus, school culture has a more dominant effect in determining WBL learning processes.

Effects of School Culture (X1), Corporate Culture (X2), Institutional Performance (X3) and WBL Learning Processes (X4) on Readiness Of Student Work (Y) (Quality Determination of Readiness Of Student Work)

The effects of school culture, corporate culture, institutional performance, and WBL learning processes on learning outcomes can be determined by testing the hypothesis: there are significant effects of school culture (X1), corporate culture (X2), institutional performance (X3) and WBL learning processes on readiness of student work (Y). To test this hypothesis, a multiple regression analysis was completed by placing $\mathrm{Y}$ as the dependent variable and $\mathrm{X} 1, \mathrm{X} 2, \mathrm{X} 3$, and $\mathrm{X} 4$ as the independent variables. The results of the multiple regression analysis are presented in Table 6.

Table 6

Results of the multiple regression analysis of Variable $\mathrm{Y}$ on Variable $\mathrm{X}_{1}, \mathrm{X}_{2}, \mathrm{X}_{3}$, and $\mathrm{X}_{4}$

\begin{tabular}{|c|c|c|c|c|c|c|c|c|}
\hline $\begin{array}{l}\text { Dep. } \\
\text { Var. }\end{array}$ & $\begin{array}{l}\text { Indep. } \\
\text { Var. }\end{array}$ & B & Beta & $\mathrm{r}_{\mathrm{par}}$ & $\begin{array}{l}\text { Partial } \\
\text { Det. }\left(\mathrm{r}_{\mathrm{par}}^{2}\right)\end{array}$ & $t_{\text {total }}$ & Sig. t & Summary \\
\hline \multirow{4}{*}{ Y } & $\mathrm{X}_{1}$ & 0.138 & 0.135 & 0.151 & 0.023 & 2.995 & 0.018 & \multirow{4}{*}{$\begin{array}{l}\mathrm{R}=0.723 \\
\mathrm{R}^{2}=0.523 \\
\mathrm{~F}=55.712 \\
\mathrm{P}<0.05 \\
\mathrm{C}=12.135\end{array}$} \\
\hline & $\mathrm{X}_{2}$ & 0.122 & 0.120 & 0.124 & 0.015 & 2.927 & 0.021 & \\
\hline & $\mathrm{X}_{3}$ & 0.239 & 0.228 & 0.250 & 0.063 & 4.320 & 0.000 & \\
\hline & $\mathrm{X}_{4}$ & 0.366 & 0.378 & 0.371 & 0.138 & 6.544 & 0.000 & \\
\hline
\end{tabular}

The multiple regression analysis on Table 6 shows that F-total is 55.712 and p-value are lower than 0.05 . As a result, the correlation coefficient $(\mathrm{R})$ of 0.523 is significant at the significance level of 0.05 . Due to the analysis, the hypothesis stating there are significant effects of school culture (X1), corporate culture (X2), institutional performance (X3), and WBL learning processes (X4) on the readiness of student work (Y) was accepted. The coefficient of determination $(\mathrm{R} 2)=0.523$ indicates that the contribution of these four variables is $52.3 \%$.

Independently, school culture (X1) has a significant effect on readiness of student work $(\beta=0.135: p>0.05)$; corporate culture (X2) has a significant effect on readiness of student work $(\beta=0.122$ : $\mathrm{p}>0,05)$; institutional performance (X3) has a significant effect on readiness of student work $(\beta=0.228$ : $p<0.05)$; and WBL learning processes $(\mathrm{X} 4)$ have a significant effect on readiness of student work $(\beta=0.378: p<0.05)$.

In response to the coefficient of partial determination, WBL learning processes provide the greatest contribution to the readiness of student work $(13.8 \%)$, followed by institutional performance $(6.3 \%)$, school culture $(2.3 \%)$, and corporate culture $(1.5 \%)$. Thus, learning processes perform a more dominant effect in determining the readiness of student work. 
Concerning the predictor value and constant of multiple regressions, the regression line can be formulated as follows: $\mathrm{Y}=12,135+0,135 \mathrm{X}_{1}+0,120 \mathrm{X}_{2}+0,228 \mathrm{X}_{3}+0,378 \mathrm{X}_{4}$. Regarding the regression line, the mean of learning outcomes will increase or decrease in the number of $0.135,0.120,0.228$, and 0.378 . Each value represents the increase or decrease of variables: school culture, corporate culture, institutional performance, learning processes, and the readiness of student work of a unit.

\section{Path Analysis (Direct and Indirect Effects)}

The direct and indirect effects were examined by testing the significance of path coefficient based on the model of empirical-causal correlation. The path coefficient which is lower than 0.05 is not significant and is excluded from the model of empiricalcausal correlations. The significance of the direct effects is known based on the beta coefficient of two regression analyses using stepwise methods, namely: (1) multiple regression of variable $\mathrm{X} 4$ on variables $\mathrm{X} 1, \mathrm{X} 2$, and $\mathrm{X} 3$, and (2) multiple regression of variable $\mathrm{Y}$ on variables $\mathrm{X} 1, \mathrm{X} 2, \mathrm{X} 3$, and $\mathrm{X} 4$. Meanwhile, the indirect effects are calculated based on the direct path coefficient according to the causal correlation model.

The empirical-causal correlation that contains a regression value $(\beta)$ or path coefficient is presented in Figure 2. Whereas, the significance of the direct effects, indirect effects, non-causal effects of the causal correlation can be found in Table 7.

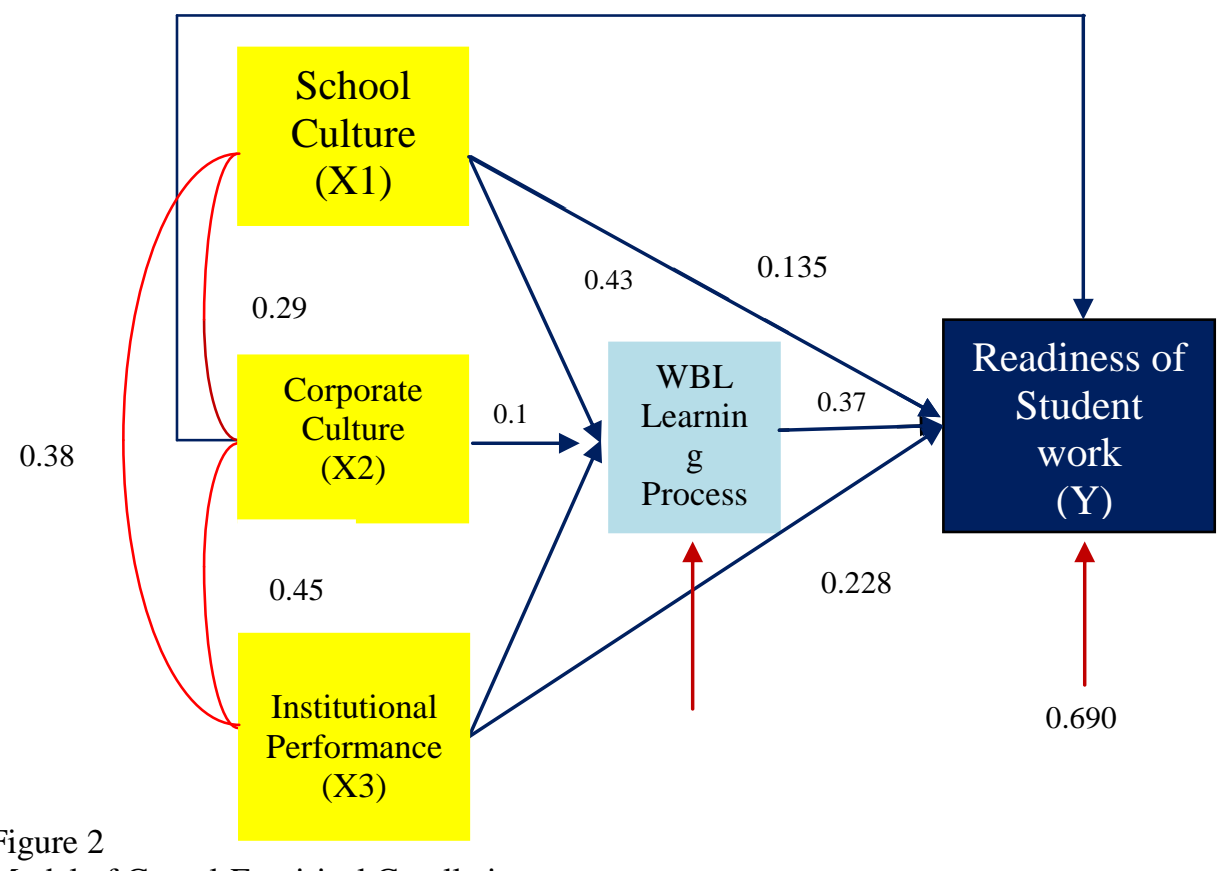

Model of Causal-Empirical Corellation 
Table 7

Results of Path Analysis

\begin{tabular}{lllllll}
\hline \multirow{2}{*}{$\begin{array}{l}\text { Dependent } \\
\text { Variables }\end{array}$} & $\begin{array}{l}\text { Independent } \\
\text { Variables }\end{array}$ & Effects & $\begin{array}{l}\text { Indirect } \\
\text { Effects } \\
\text { Through } \mathrm{X}_{4}\end{array}$ & $\begin{array}{l}\text { Total } \\
\text { Effects }\end{array}$ & $\begin{array}{l}\text { Non- } \\
\text { Causal } \\
\text { Effects }\end{array}$ & Correlation \\
\hline \multirow{3}{*}{$\mathrm{X} 4$} & $\mathrm{X}_{1}$ & 0.430 & - & 0.430 & 0.101 & 0.531 \\
\cline { 2 - 7 } & $\mathrm{X}_{2}$ & 0.107 & - & 0.107 & 0.124 & 0.231 \\
\cline { 2 - 7 } & $\mathrm{X}_{3}$ & 0.360 & - & 0.360 & 0.088 & 0.448 \\
\hline \multirow{3}{*}{$\mathrm{Y}$} & $\mathrm{X}_{1}$ & 0.135 & 0.058 & 0.193 & 0.081 & 0.274 \\
\cline { 2 - 7 } & $\mathrm{X}_{2}$ & 0.120 & 0.013 & 0.133 & 0.239 & 0.372 \\
\cline { 2 - 7 } & $\mathrm{X}_{3}$ & 0.228 & 0.082 & 0.310 & 0.235 & 0.545 \\
\cline { 2 - 7 } & $\mathrm{X}_{4}$ & 0.378 & - & 0.378 & 0.273 & 0.651 \\
\hline
\end{tabular}

The direct and indirect effects can be summarized as follows:

a. The direct effect of school culture on the readiness of student work is significant.

b. The indirect effect of school culture on the readiness of student work through WBL learning processes is significant.

c. The direct effect of corporate culture on the readiness of student work is significant.

d. The indirect effect of corporate culture on learning outcomes through WBL learning processes is significant.

e. The direct effect of institutional performance on the readiness of student work is significant.

f. The indirect effect of institutional performance on the readiness of student work through WBL learning process is significant.

The direct effect of WBL learning processes on the readiness of student work is significant.

\section{DISCUSSION}

Regarding the correlation analysis among variables, the relationship among variables is categorized as high. The lowest correlation is achieved by the relationship between corporate culture and learning outcomes $(r=0.231)$. Meanwhile, the highest correlation is performed by the relationship between WBL learning processes and the readiness of student work $(r=0.651)$. The high correlation between WBL learning processes and the readiness of student work indicates that WBL learning processes have a significant effect on the learning outcomes. The research finding is relevant to the study conducted by Klatt (2017) which proves that the use of Work-Based Learning (WBL) in teaching and learning processes will provide positive effects on the students' achievement, motivation, and continuation of education. WBL program will improve the learning outcomes if the program objectives, curriculum, and internship are designed, applied, and evaluated properly (Billett, 2016). 
The hypothesis testing shows that there are significant effects of school culture, corporate culture, institutional performance, and learning processes on learning outcomes. Independently, school culture, corporate culture, institutional performance, and learning processes have significant effects on the readiness of student work. It indicates that the levels of the readiness of student work are affected by the quality of school culture, corporate culture, institutional performance and learning processes.

The results are in line with various studies which reveal that the readiness of student work are affected by the learning processes (McGrath, 2016). Furthermore, it is stated that a learning process is indicated by the interactions between lecturers and students. The interactions quality is determined by the lecturer's readiness to teach and students' readiness to learn. The learning process which is intervened by applying problem-based learning can greatly improve the students' achievement (Astutik \& Prahani, 2018). In addition, improvements in learning processes using various teaching methods will improve the quality. The studies reveal that positive interventions on the learning process will improve students' learning outcomes.

The findings are also in line with Kaplan (2013), stating school culture supports learning outcomes. It is reasonable because school culture has some aspects: collaborative leadership, teacher collaboration, professional development, collegial support, the unity of purpose, and learning partnership. Thus, the effort to improve learning outcomes can be supported by school culture through enhancement, understanding, values internalization, norms, and beliefs in achieving the learning objectives.

The effectiveness of school organizations is determined by culture involving formation, processes, work climate, values, and norms. The culture will lead to the successful teaching and learning processes. It is further stated that schools with a more developed and responsive work culture are commonly more sensitive to the changing students' needs (Cimatti, 2016). The dimension of school culture is the actualization of four main indicators: professional collaboration, affiliation relationship, collegial relationship, and efficacy or self-determination. The research findings indicate that school culture can be observed through these four indicators.

Efforts to improve the school culture cannot be separated from the description of various components and indicators that foster it. Some strategic efforts to be done are: (1) improving togetherness among students through various programs and activities so that students feel worthy and excited in supporting each other, (2) developing relationship among students, lecturers, and staffs so that a qualified collaboration in conducting the learning processes is achieved, (3) generating the academic climate and therefore students may fulfil their learning needs by improving skills professionally, and (4) enhancing professional collaborations among students, lecturers, and staff through discussions and sharing.

The dimension of institutional performance is comprehensively defined as an actualization of three factors. The factors are a performance in completing primary tasks (planning, implementing and evaluating the learning), performance in completing secondary tasks, and performance in developing professionalism. Efforts to improve 
institutional performance cannot be separated from both various components and indicators that foster it. Considering the results of this study, the strategic efforts to be done are: 1) improving the institutional performance, especially the aspects of professional development such as supervision, monitoring, and evaluation, (2) improving performance in completing secondary tasks by providing more opportunities to play a role in various activities, (3) improving the ability to plan the learning as the implementation of the agreed curriculum, (4) improving the ability to carry out learning processes concerned with teaching methods, media, and evaluations.

The results are in line with the study, which concludes that there is a relationship between commitment and some organizational variables such as: (a) discipline, (b) leadership style, (c) performance, (d) employee turn-over, (e) communication, (f) involvement in the network, (g) participation in making decisions, (h) feedbacks, and (i) organizational socialization strategy (Hurrell,2016).

The learning process of machining practices by applying WBL model is reflected from: 1) an optimal collaboration among lecturers, instructors and industry supervisors in solving problems based on the expertise, 2) a growing sense of comfort among lecturers, instructors and industry supervisors to perform tasks based on their rights and authorities, and 3) a high collegiality among lecturers, instructors, and industry supervisors to foster passions to work professionally. Thus, the learning process in machining practices performs a high expectation to actualize the aims of vocational education.

\section{CONCLUSION}

1. The effects of school culture, corporate culture, institutional performance, and WBL learning processes on the readiness of student work in machining practices are positive and significant $(\mathrm{r}=0.723 ; \mathrm{p}<0.05)$. The contribution of the four variables is $52.3 \%$.

2. With regard to the predictor value and constant of the multiple regression analysis, the regression line equation can be formulated as follows: $\mathrm{Y}=12.135+0.135 \mathrm{X}_{1}+0.120 \mathrm{X}_{2}+0.228 \mathrm{X}_{3}+0.378 \mathrm{X}_{4}$

3. Concerning the coefficient of partial determination, WBL learning processes provide the highest contribution to the readiness of student work $(13.8 \%)$, followed by institutional performance $(6.3 \%)$, school culture $(2.3 \%)$ and corporate culture $(1.5 \%)$. In conclusion, WBL learning processes more dominantly affect the readiness of student work in machining practices.

4. School culture, corporate culture, and institutional performance through WBL learning processes both directly and indirectly provide significant effects on the readiness of student work in machining practices.

5. WBL learning processes directly affect the readiness of student work in machining practices.

\section{REFERENCES}

Arie de Geus. (2002). The living company: Habits for survival in a turbulent business environment. London: Harvard Business Review Press. 
Astutik, S., \& Prahani, B. K. (2018). The practicality and effectiveness of collaborative creativity learning (CCL) model by using PhET simulation to increase students' scientific creativity. International Journal of Instruction, 11(4), 409-424.

Axmann, M., Rhodes, A., \& Nortdstrum, L. (2015). Vocational teachers and trainers in a changing world. the imperative of high-quality teacher training systems. Geneva: ILO.

Balkar, B. (2015). Defining an empowering school culture (ESC): Teacher perceptions. Issues in Educational Research, 25(3), 205-213.

Bern, R. B., \& Erickson, P. M. (2001). Contextual teaching and learning: Preparing student for the new economy, Columbus, Ohio: Career and Technical Education National Dissemination Center.

Billett, S. (2016). Apprenticeship as a mode of learning and model of education. Education and Training, 58(6), 613-628.

Calhoun, C. C., \& Finch, A. V. (1982). Vocational education: Concepts and operations. Belmont: Wadsworth Publishing Company.

Cheong, Y. C. (2000) Cultural factors in educational effectiveness: A framework for comparative research. School Leadership and Management, 20(2), 207-225.

Cimatti, B. (2016). Definition, development, assessment of soft skills and their role for the quality of organizations and enterprises. International Journal for Quality Research, 10(1), 97-130.

Clarke, L., \& Winch, C. (2008). Vocational education. International approaches, developments and systems. London \& New York: Routledge.

Ebel, R.L. (1972). Essentially of educational measurement. New Jersey: Prentice Hall.

Evans, Rupert N., \& Herr, Edwin L. (1978). Foundation of vocational education parts 4: Organization of vocational education. Columbus: Charles E. Merrill Publishing Company.

Feldt, Leonard S. Robert., \& Brennan Robert L. (1989). Reliability educational measurement. New York: McMillan Publishing Company.

Finch, C. R., \& Crunkilton, J. R. (1984). Curriculum development in vocational education. Boston: Allyn and Bacon Inc.

Fosnot, C. (1996). Constructivism: A psychologycal theory of learning. Dalam C. Fosnot (Editor): Constructivism: Theory, perspectives, and practice. New York: Teachers College.

Hardwick-Franco, K. G. (2018), Flexible education in Australia: A reflection from the perspective of the UN's sustainable development goals. Higher Education, Skills and Work-based Learning, 8(3), 259-273. 
Hurrell, S. A. (2016). Rethinking the soft skills deficit blame game: employers, skills withdrawal and the reporting of soft skills gaps. Human Relations, 69(3), 605-628.

Kaplan, L. S., \& Owings, W. A. (2013). Culture re-boot: reinvigorating school culture to improve student outcomes. Thousand Oaks: Corwin Press.

Karen Vaughan. (2017)."The role of apprenticeship in the cultivation of soft skills and dispositions.” Journal of Vocational Education \& Training. 69/3: 540-557.

Keep, E. (2015). Unlocking workplace skills: What is the role for employers? (Policy Report). Oxford: Centre on Skills, Knowledge \& Organizational Performance, Oxford University.

Klatt, M, Clarke, K., \& Nicky, D. (2017). Working their way to school completion: a snapshot of School-based Apprenticeships and Traineeships for young Australians. Journal of Vocational Education \& Training , 69(2), 473-494.

Lorsbach, A., \& Tobin, K. (1992). Constructivism as a referent for science teaching. NARST research matters-to the science teacher, No. 30. Garnett, J. (2008). Recognizing and enhancing the quality of university work-based learning programmes. Proceedings of the work-based learning futures II conference, UK, Middlesex, May 2008, 32-38.

Lynch, R. L., \& Harnish, D. (1998). Preparing pre-service teachers education students to used work-based strategies to improve instruction. In Contextual teaching and learning: Preparing teachers to enhance student success in the workplace and beyond (pp. 127158). Columbus: OH: ERIC Dearing house on Adult, Career, and Vocational Education.

McGrath, S., \& Powell, L. (2016). Skills for sustainable development: Transforming vocational education and training beyond 2015. International Journal of Educational Development, 50(2), 12-19.

Nunnally, J.C. (1978). Psychometric theory. New York: McGraw-Hill Inc.

Österlind, E. (2018), Drama in higher education for sustainability: work-based learning through fiction? Higher Education, Skills and Work-based Learning, 6(3), 337-352.

Paris, K. A., \& Mason, S. A. (1995). Planning and implementing youth apprenticeship and work-based learning. Wisconsin: Center on Education and Work, University of Wisconsin.

Pässilä, A., Owens, A., Kuusipalo-Määttä, P., Oikarinen, T., \& Benmergui, R. (2017), Beyond text: the co-creation of dramatised character and iStory. Journal of Work Applied Management, 9(2), 159-169.

Rooney, D., Hopwood, D., \& Kelly, M. (2015). The role of simulation in pedagogies of higher education for the health professions: Through a practice-based lens. Vocations and Learning, 8(1), 269-285.

Shefi, Y. (2005) The resilient enterprise: Overcoming vulnerable for competitive advantage. ( $1^{\text {st }}$ Edition). Cambridge MA: MIT Press. 
Skulmoski, G. J., Hartman, F. T., \& Krahn, J. (2007). The Delphi method for graduate research. Journal of Information Technology. 6(1), 112-135.

Smith, E. (2002). Theory and practice: the contribution of off-the-job training to the development of apprenticeship and trainee. Journal of Vocational and Education Training, 54(3), 431-456.

Thorndike, R. L., \& Hagen, E. P. (1984). Measurement and psychology in education. New York: John Wiley and Sons.

Trisiswanto, B. (2012). Model Penyelenggaraan WBL pada pendidikan Vokasi Diploma III Otomotif. Jurnal pendidikan Vokasi, 2(1), 11-25.

Wall, T., Bellamy, L., Evans, V., \& Hopkins, S. (2017). Revisiting impact in the context of workplace research: a review and possible directions. Journal of Work Applied Management, 9(2), 95-109.

Wall, T., Hindley, A., Hunt, T., Peach, J., Preston, M., Hartley, C., \& Fairbank, A. (2017). Work-based learning as a catalyst for sustainability: a review and prospects. Higher Education, Skills and Work-Based Learning, 7(2), 211-224.

Wall, T., \& Hindley, A. (2018), Work integrated learning for sustainability education. In Leal, et al. (Eds), The encyclopedia of sustainability in higher education. Springer, forthcoming.

Wall, T., \& Meakin, D. (2018). Reflective practices for sustainable development. In Leal Filho, W. (Ed.), Encyclopedia of sustainability in higher education. Springer Nature, forthcoming.

Wonacott, M. E. (2002). The impact of work-based learning on student. ERIC Digest, 242 (EDO-CE-02-242) ERIC Clearinghouse on Adult, Career, and Vocational Education. 